\title{
LINEATION IN COMPLEX FOLD SYSTEMS
}

SIR,-The emphasis placed by Clifford et al. (Geol. Mag., xciv, 1956, pp. 1-24) on the desirability of mapping structures in metamorphic areas on all scales of magnitude may provide an occasion for quoting once again the wise words of Prof. Bruno Sander- " There ought not to be microtectonists and megatectonists working independently of each other, but rather one group of workers investigating the correlations between processes in large and in small units ... Geology needs petrofabric analysis not less than petrofabric analysis needs geology." As one, however, whose concern for many years has been with the microstructures of rocks (a study of which " microtectonics " forms only one of many aspects, albeit a highly interesting one), I observe with some satisfaction that structural geologists are now reaching fairly general agreement concerning the validity of a relationship between microfabric, lineation, folding, and regional metamorphism in the Moines which I first claimed twenty years ago. When put forward in 1937 this claim rested solely upon a study of the microfabric; its ultimate acceptance, after widespread doubt and criticism, confirms in a striking manner the soundness of the foundations laid by Prof. Sander and Prof. Schmidt, pioneers whose work has been little appreciated in this country. The history of investigations in the Scottish Highlands scarcely supports the contention of the authors that " it is premature to discuss the significance of the linear structures (or of the microfabric) until one has established the nature of the associated folds". There has admittedly been much inconsequential argument, mostly between those who have never made a detailed study of the microfabrics in question. But "premature" ? Rather would I assert that the microtectonists have been whole strides ahead of their megatectonist colleagues in being able to demonstrate to them the real significance of the structures which they were mapping, at a time when they themselves were still talking of " north-easterly strike " and " direction of stretching ".

The authors (ibid., p. 23) "dissent from Phillips' view that the regional folding of the Moines occurred about N.W.-S.E. axes" because they have found folds which do not plunge to the south-east. They describe this as being evidence " in flat disagreement " with my deduction. The use of this rather emphatic expression will suggest to most readers that I have made statements about the non-occurrence of folding with other than southeasterly plunging axes. I have done nothing of the kind, and would indeed be quite astonished if, as one penetrated into the heart of the Caledonian range, one failed to find folding with Caledonian trend ! What I have done is to draw attention to the evidence (as revealed in the fabric) that during the early regional metamorphism of a part of the Moines folding about axes almost at right angles to the Caledonoid trend developed as an important and widespread structure. The suggested correlation with pre-Torridonian folding in the Foreland, made tempting by the coincidence of direction across the marginal fracture zone (a coincidence found also on the opposite flank), is weakened as developing knowledge of folding within the Caledonides demonstrates relationships of the kind described by the authors. Possibly it may ultimately have to be abandoned, but I shall watch with interest the unfolding of the final structural synthesis which will accommodate that eventuality.

\section{REFERENCE}

SANDER, B., 1934. Petrofabrics (Gefügekunde der Gesteine) and Orogenesis. Amer. Journ. Sci., ccvii, 37-50.

Department of Geology, F. C. Phillips.

THE UNIVERSITY, BRISTOL. 